\title{
Assessment of Passenger Satisfaction with Intra-City Public Bus Transport Services in Abuja, Nigeria
}

\author{
Ali Alphonsus Nwachukwu \\ University of Nigeria, Nsukka
}

\begin{abstract}
The aim of this study was to investigate passenger satisfaction with the service quality attributes of public bus transport services in Abuja, Nigeria. To achieve this, a survey was conducted between February and July 2011. In 10 sample bus stop areas selected for this study, 300 public bus transport users were randomly selected to elicit their overall satisfaction and factors that influenced their satisfaction in the use of public bus transport services in Abuja using a self-rated questionnaire. Data obtained were analyzed using descriptive statistics, correlation, and principal component and regression analyses. The results of these analyses showed that passengers were not satisfied with the public bus transport services in Abuja. Using Principal Component Analysis (PCA), four underlying factors were extracted that influenced passenger satisfaction with public bus transport services in the city. The four components together explained 83.87 percent of the cumulative variance of PCA, leaving 16.32 percent of the total variance unexplained. The standardized regression coefficients further showed that comfort has the greatest impact on overall satisfaction, followed by accessibility. Adequacy and bus stop facilities were the third and fourth factors in the order of relative importance in influencing passenger satisfaction of
\end{abstract}


public bus transport services in the city. On the basis of the findings, recommendations were made to improve public bus transport services in the city of Abuja.

\section{Introduction}

Transport needs of major cities in Nigeria now present significant challenges for policy makers as unpredictable shifts in population dynamics in response to the need for employment, housing, and sustenance continues. The expansion of the cities in Nigeria, coupled with increasing urban population, results in greater demand for transport provision. This demand has, however, not always been met, and efforts to provide adequate transport infrastructural facilities are ad hoc, uncoordinated, and poor (Aderamo 2008).

Commonly identified urban transport problems in Nigerian cities are long waiting times for buses, traffic congestion, parking difficulties, air pollution, and traffic accidents (Asiyanbola 2007; Aderamo 2010; Ashiedu 2011). This is because of the increasing travel demand and preferences in using private vehicles in Nigerian cities (Afolabi 2008; Banjo 2008). To prevent more problems caused by the rise in demand for urban transport and increase in private motorization, it is highly recommended by many researchers as well as public decision makers to provide an attractive public transport service as an alternative transport mode in many cities (Banjo 2008, Federal Government of Nigeria 2010).

Public transport, by definition, connotes the act or the means of conveying a large number of people en masse, as opposed to conveyance in individual vehicles carrying very few people at a time. Public transport comprises mainly rail systems, light rail systems, tramways and monorails, bus systems, and, where possible, water transport. The choice of any or a combination of these public transport systems could be influenced by the population and area of a city. Given the low level of technological development in Nigeria, the bus system was chosen in this study. The bus system is the transport system that uses buses that may have a range of passenger capacities and performance characteristics and may operate on fixed routes with fixed schedules or may be flexibly routed (Smerk 1974). Bus systems have the potential of extending transport services to greater proportions of urban residents who do not have private cars and cannot afford frequent taxi fares (Andeleeb et al. 2007). They have the potential of being used as policy tools to reduce the number of cars on urban roads and thus reduce traffic chaos in cities. Despite the vital role that buses are able to play in any urban area, their services in Nigerian cities are frequently insufficient to meet demand, and the services provided suffer from 
low output (Ali and Onokala 2009). As a result, often, they have a negative public image.

The transport system in Abuja, the Federal Capital Territory (FCT), caters to more than 1.5 million people and faces numerous and significant challenges, efforts of the federal government to improve the system notwithstanding. The complex and heterogeneous traffic pool, largely dominated by private vehicles, most of which are poorly maintained, and inadequate enforcement of traffic rules in Abuja creates serious and unbearable congestion and heavy pollution of the city environment (Chung 2010). This situation is further compounded by the dwindling efficiency of service delivery of the Abuja Mass Transit bus services (Oiboh 2010). To improve the public bus transport system in Abuja, it is important to elicit insights from actual passengers of the system about changes they would like to see to better meet their needs. This is because the provision of public bus transport services is passenger-centered. By identifying the key dimensions that offer value and influence passenger satisfaction, alternative bus strategies can be devised so that more people (especially private car owners) opt in favor of this service. In turn, this would alleviate the present traffic congestion and related problems faced by the city of Abuja and its population.

Previous studies on public bus transport services at national and local levels focused on constraints (Aworemi 2009; Aderamo 2010), impacts (Gbadamosi 2009; Ashiedu 2011), and the effect of congestion on vehicle movement (Ibitoye et al.2012), but there is scant literature on passenger satisfaction with levels of public bus service provision in Nigerian cities. To keep and attract more bus passengers, public bus transport must have high service quality to satisfy and fulfill a wider range of different passenger needs. Increases in passenger satisfaction are translated into retained markets, increased use of the system, new customers, and more positive public image. To accomplish these ends, transit needs reliable and efficient methods for identifying the determinants of service quality from customer perceptions. Thus, the focus of this paper is to investigate the service quality attributes that influence passenger satisfaction with the public bus transport system in Abuja.

Two basic objectives of this study are to identify important factors determining service quality of public bus transport system in Abuja that explain passenger satisfaction and to evaluate the relative importance of these factors to determine the priority of quality improvements to enhance passenger satisfaction. 


\section{Study Area}

The Abuja Federal Capital Territory is located in the center of Nigeria. It covers an area of about $8,000 \mathrm{~km}^{2}$ and is bordered on all sides by four states: Kaduna State to the north, Niger State to the west, Nassarawa State to the east and Kogi State to southwest (Dawan 2000). According to the National Population Commission (NPC) (2007), the population of Abuja in 2006 was 1,406,239 persons with a growth rate of 9 percent. Abuja Federal Capital Territory comprises six Area Councils: Abuja Municipal, Bwari, Gwagwalada, Kuje, Abaji. and Kwali (Figure 1.)

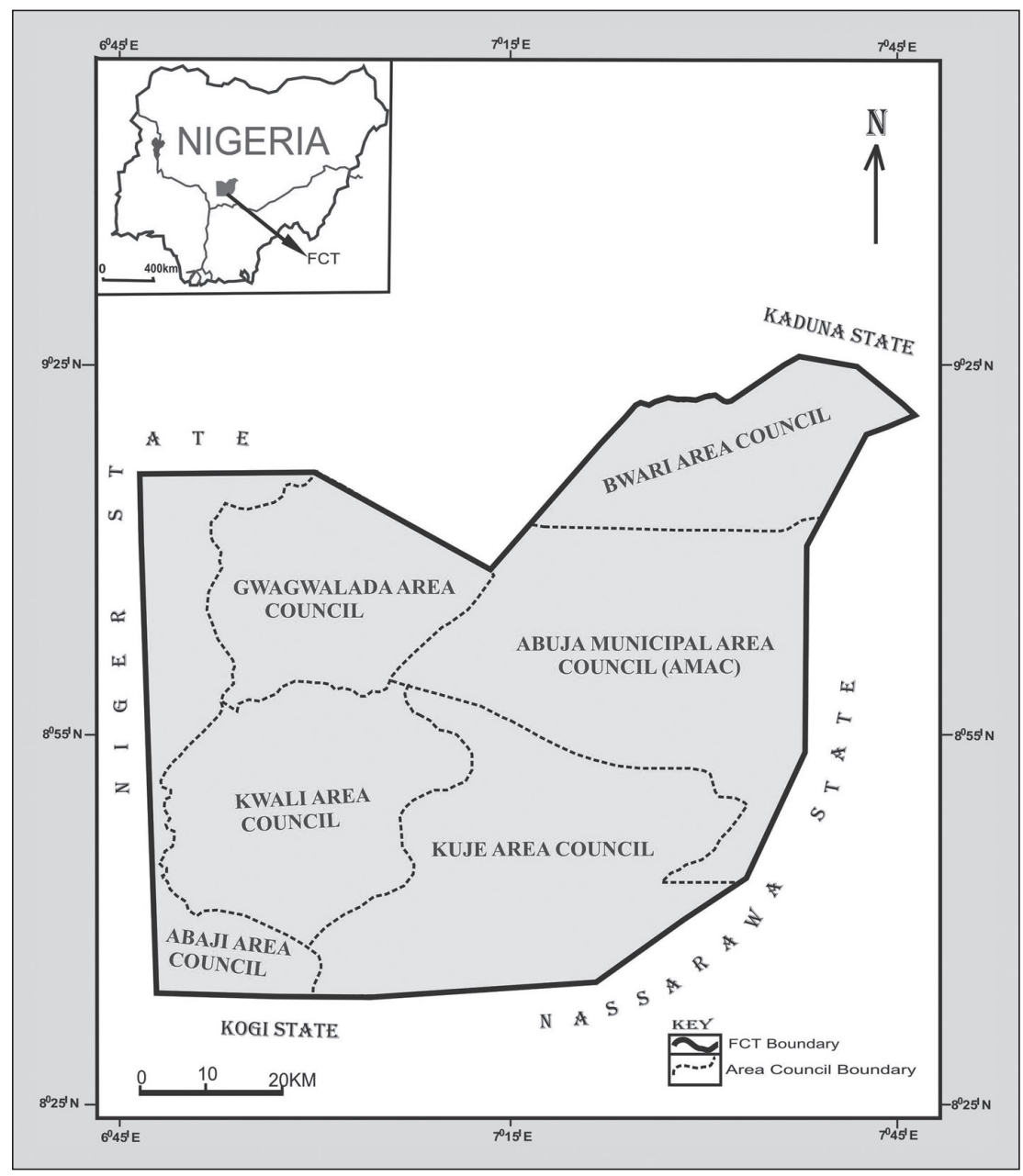

Source: Abuja Geographical Information System (AGIS), 2004

Figure 1. Map of Federal Capital Territory, Abuja 


\section{Concepts of Passenger Satisfaction and Service Quality Attributes}

An improvement to a supplied service quality can attract more users. This fact could resolve many problems (e.g., helping to reduce traffic congestion, air and noise pollution, and energy consumption) because individual transport would be used less (Eboli and Mazzulla 2007).

On one hand, satisfaction is defined as customer fulfillment (Oliver 1997). It is a judgment that a product or service feature or the product or service itself provides a pleasurable level of consumption-related fulfillment, including levels of under- or over-fulfillment (Budiono 2009). Satisfaction is defined as "fulfillment of a need, demand, claim, desire, etc." Need fulfillment is a comparative process giving rise to satisfaction responses. The dominant theoretical model employed in research into customer satisfaction is the expectancy/disconfirmation model in which customers are satisfied (dissatisfied) if their experience and perceptions of the service they perceive exceed (fall short of) their expectations (Payne and Holt 2001). Within this framework, satisfaction is analyzed by examining the expectation of service quality and the attributes of the service quality that influence the experience and perceptions. On the other hand, service quality is defined as a comparison between customer expectation and perception of service (Gronroos 1984).

Service quality, in general, consists of five distinct dimensions: tangibles (physical facilities, equipment, appearance of personnel); reliability (ability to perform the promised service dependably and accurately), responsiveness (willingness to help customers and provide prompt service), assurance (knowledge and courtesy of employees and their ability to inspire trust and confidence), and empathy (caring or the individualized attention a firm provides its customers) (Budiono 2009). Quality is one of the key dimensions that is factored into consumer satisfaction judgments. Quality is the totality of features and characteristics of a product or service that bear on its ability to satisfy stated and implied needs. In the short term, product or service features determine quality, which then satisfies customer needs.

Several studies regarding satisfaction and dissatisfaction in public transport have been conducted to develop and create attractive public transport. The Department for Transport (2003) identified high frequency of service, services that are reliable, and fares that offer value for money as important needs of UK public transport users. In India, transport systems have also been criticized for their low quality of services, reflected in the growing number of standing passengers, lack of punctuality, irregularity, and substandard amenities (Mishra and Nandagopal 1993). Negative critical incident and customer/passenger dissatisfaction could be a 
constraint for people to continue using public transport (Friman et al. 2001; Friman and Garling 2001). Based on the factors/attributes identified in the above reviewed studies, the author's personal experiences with bus services, in-depth interviews with the bus passengers, and brainstorming, attributes of public bus transport services that influence bus passengers satisfaction were constructed and used in this study in Abuja.

\section{Methodology}

\section{Sampling and Data Collection}

Data were collected by the use of a questionnaire, field observations, and oral interviews between February and July 2011. The questionnaire used in study was based on the published studies reviewed in this work, as well as in-depth interviews and extensive brainstorming. Abuja bus commuters (both transit-dependent and choice transit riders) were the target population in this study because they are homogeneous in their use of buses but heterogeneous in their other characteristics (profession, age, income, mobility, and the like). Their judgments or opinions mainly sought were because they would be best able to evaluate the existing levels of public bus services and levels of satisfaction with such services in Abuja. Ten major bus stop areas (clusters) in Abuja were selected as sample sites for this survey (Figure 2). From each bus stop area, systematic sampling was used to select households on the left or right of randomly-selected streets. Respondents from each household were selected to participate if they use bus services in the city and were between ages of 15 and 60 . They were chosen because people in these ages have a routine commuting travel behavior.

A self-rated questionnaire was used to collect data for this study. Respondents were asked to rate their overall satisfaction with public bus transport services and factors/attributes of public bus transport services that influence their satisfaction (Table 1).The attributes of public bus transport service that influence bus passenger satisfaction used in this work were based on published studies reviewed for this work, extensive brainstorming, in-depth interviews with bus passengers, and the author's personal experiences with public bus transport services. A five-point Likert scale with "strongly agree" equal 5, "agree" equal 4, "undecided" equal 3, "disagree" equal 2 , and "strongly disagree" equal 1 was used in the rating. 


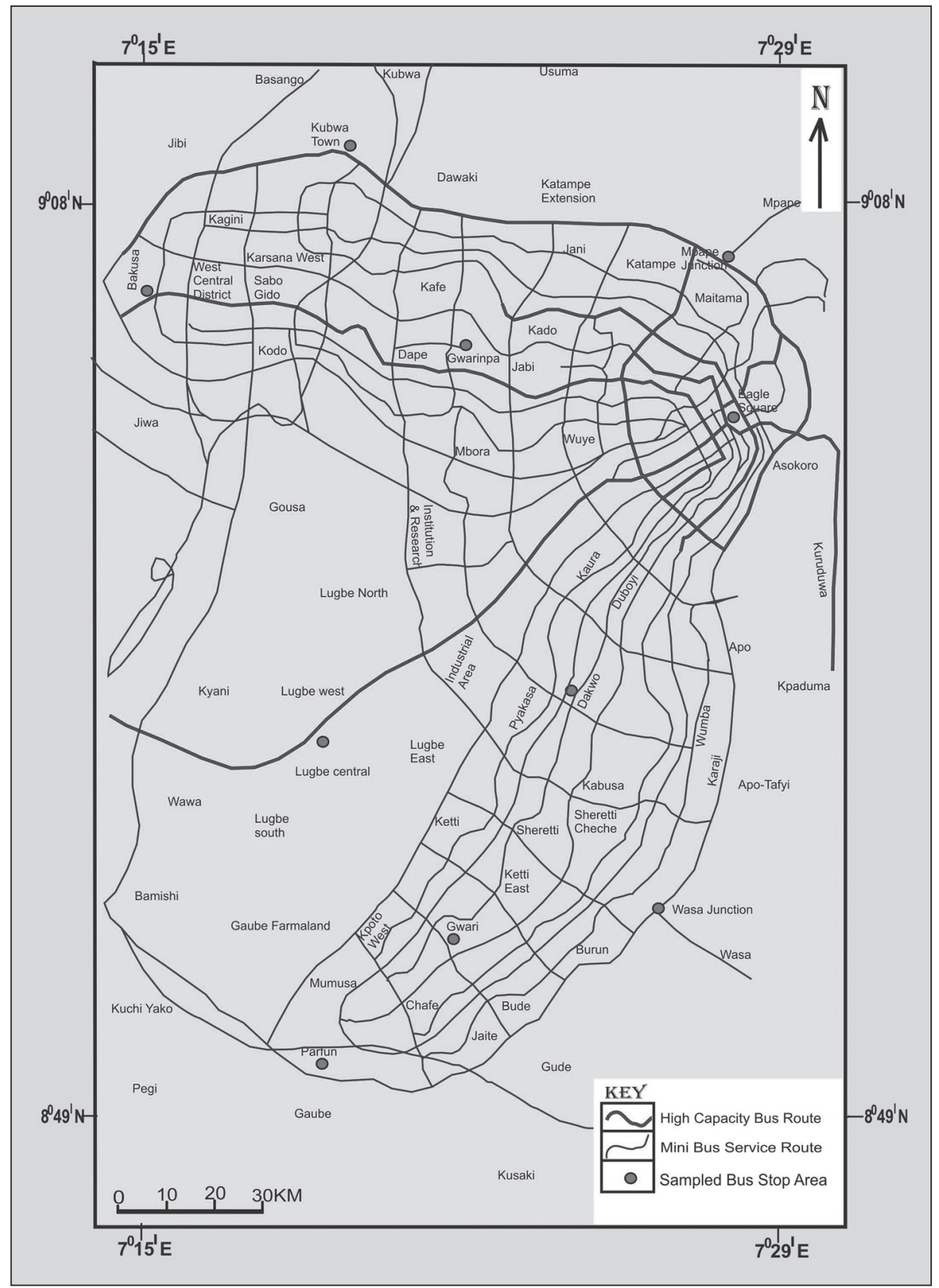

Source: Office of the Secretary, Transportation FCT, Abuja, 2011

Figure 2. Bus route network in Federal Capital Territory, Abuja 


\section{Table 1. Public Bus Service Quality Attributes Measures}

\begin{tabular}{|c|l|}
\hline Variable Code & Variable Description \\
\hline OS & Overall satisfaction with public bus transport services \\
\hline S1 & Seats generally available in buses \\
\hline S2 & Enough leg-space in buses \\
\hline S3 & Frequency of bus service \\
\hline S4 & Short waiting time at bus stop \\
\hline S5 & Facilities inside buses are in good condition \\
\hline S6 & Bus stops have enough shelters \\
\hline S7 & Ceiling heights of buses are comfortable \\
\hline S8 & Buses are well maintained \\
\hline S9 & Short passenger walking distance to bus stops \\
\hline S10 & Sufficient benches available at bus stops \\
\hline S11 & Sufficient number of buses in city \\
\hline S12 & Transport price affordable \\
\hline S13 & Safety of passengers on board \\
\hline S14 & Not afraid of being pickpocketed on bus \\
\hline S15 & Buses provide short travel time \\
\hline S16 & Drivers and conductor behave well \\
\hline S17 & Buses are clean inside \\
\hline & \\
\hline
\end{tabular}

Thirty respondents were systematically sampled and administered the questionnaire in each of the 10 spatially-segregated and randomly-selected major bus stop areas (Figure 2), giving a total of 300 respondents sampled for this study. Of the 300 respondents, 191 respondents were transit-dependent riders, representing 64 percent of the public bus passengers interviewed; 109 respondents were choicetransit riders, representing 36 percent of the passengers interviewed (Table 2).This was done to capture the responses of all categories of public bus users in the city for an in-depth understanding of their problems. Internal consistency for the scale was examined using Cronbach's alpha $(\alpha$.) 


\section{Table 2. Distribution of Passengers Interviewed among Bus Stop Areas}

\begin{tabular}{|c|c|c|c|c|c|c|c|}
\hline & $\begin{array}{l}\text { Sampled Bus } \\
\text { Areas }\end{array}$ & \multicolumn{2}{|c|}{$\begin{array}{c}\text { Transit -Dependent } \\
\text { Riders }\end{array}$} & \multicolumn{2}{|c|}{$\begin{array}{l}\text { Choice Transit } \\
\text { Riders }\end{array}$} & \multicolumn{2}{|c|}{$\begin{array}{c}\text { Total Passengers Interviewed } \\
\text { per Sample Bus Stop Area }\end{array}$} \\
\hline & & \# & $\%$ & $\#$ & $\%$ & \# & $\%$ \\
\hline 1 & Kubwa Town & 17 & 57 & 13 & 43 & 30 & 100 \\
\hline 2 & Mpape Junction & 18 & 60 & 12 & 40 & 30 & 100 \\
\hline 3 & Bakusa & 20 & 67 & 10 & 33 & 30 & 100 \\
\hline 4 & Gwarinpa & 19 & 76 & 11 & 24 & 30 & 100 \\
\hline 5 & Eagle Square & 24 & 80 & 6 & 20 & 30 & 100 \\
\hline 6 & Dakwo & 21 & 70 & 9 & 30 & 30 & 100 \\
\hline 7 & Lugbe Central & 18 & 60 & 12 & 40 & 30 & 100 \\
\hline 8 & Gwari & 16 & 53 & 14 & 47 & 30 & 100 \\
\hline 9 & Wasa Junction & 22 & 73 & 8 & 27 & 30 & 100 \\
\hline \multirow[t]{2}{*}{10} & Panun & 16 & 53 & 14 & 47 & 30 & 100 \\
\hline & Study Area & 191 & 64 & 109 & 36 & 300 & 100 \\
\hline
\end{tabular}

Analysis of overall satisfaction (dependent variable) and specific service quality attributes (independent variables) was based on the frequency values obtained from the self-rated questionnaire. The frequency values are the number of times respondents mentioned a variable as their answers or options. This enabled us to obtain the mean scores, standard deviations, and variances of the frequency counts of the response values. Adding all the ratings (strongly $=5+$ agree $=4+$ undecided $=3$ + disagree $=2+$ strongly disagree $=1$ ] gave us 15 points for overall satisfaction and for each of the specific service quality attributes that affect passenger satisfaction.

Thus,

$$
\mathrm{Q}=\frac{\sum f \mathrm{x}}{\mathrm{N}}
$$

Where,

$$
\begin{aligned}
& \mathrm{Q}=\text { mean } \\
& \sum=\text { summation } \\
& \mathrm{Fx}=\text { frequency of } \mathrm{x} \\
& \mathrm{N}=\text { number of occurrences }
\end{aligned}
$$


By summing the nominal values and dividing by the total number of scaling variables, the cut-off point is determined. Thus,

$$
\mathrm{Q}=\sum_{\mathrm{N}} \mathrm{f \textrm {x }}=\frac{15}{5}=3.0
$$

Dividing the total ratings of each variable gives us a mean of 3 . Thus, any mean above 3 indicates passenger satisfaction and below 3 indicates passenger dissatisfaction with service quality attributes and overall satisfaction of the public bus transport system. A mean of exactly 3 shows undecided on satisfaction level. Correlation analysis was performed to measure the linear relationship between the variables. Then, Principal Component Analysis was used to extract the major underlying dimensions of service quality attributes influencing passenger satisfaction. Thereafter, a regression analysis was performed to evaluate the effect of each underlying factor on overall satisfaction.

\section{Results and Discussion}

\section{Analysis of Frequency Distribution}

The statistical frequency distribution of respondents' perception of the overall satisfaction and specific service quality attributes that affect their satisfaction of public bus transport services in the city of Abuja is shown in Table 3. From Table 3, the perceived overall satisfaction of public bus transport services by passengers scored 33.7 percent for "disagree." "Strongly disagree" scored 20.3 percent, "agree" scored 29.3, and "undecided" scored 16.7 percent. "Strongly agree" scored zero percent. With a mean of 2.6 (mean < 3.0), a standard deviation of 0.5 , and a variance of 0.4 , the overall satisfaction of public bus transport services has been unsatisfactorily perceived by passengers in the city.

The specific service quality attributes of public bus transport services that affect passenger satisfaction were also poorly perceived (Table 3). For instance, variable S1 (seats are generally available in buses), with a mean score of 2.2 (mean < 3. 0), a standard deviation of 0.3 , and a variance 0.1 , recorded 53.7 percent under "disagree" and 18.3 percent under "strongly disagree," for a total of 72 percent for both. "Undecided" and "agree" scored 21.7 percent and 6.3 percent, respectively, and "strongly agree" scored zero percent. Variable S15 (buses provide short travel time) recorded 55.7 percent for "disagree" and 12.7 percent for "strongly disagree." The scores for "agree" and "undecided" were 26 percent and 5.3 percent, respectively; "strongly agree" was 0.3 percent with the mean score of 2.5 (mean < 3.0), a standard deviation of 0.3 , and a variance of 0.2 . 


\begin{tabular}{|c|c|c|c|c|c|c|c|c|c|c|c|c|c|c|c|c|c|c|c|}
\hline $\begin{array}{c}\stackrel{\Xi}{E} \\
\stackrel{\frac{\pi}{2}}{\frac{\pi}{J}} \\
>\end{array}$ & & 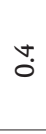 & $\overline{0}$ & $\tilde{0}$ & $\tilde{o}$ & กั & $\mathfrak{o}_{0}^{n}$ & $\stackrel{n}{0}$ & กี & $\tilde{\sigma}$ & $\stackrel{\sim}{0}$ & $\stackrel{n}{0}$ & $\check{0}$ & $\stackrel{\sim}{0}$ & $\stackrel{t}{0}$ & กั & $\tilde{0}$ & 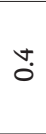 & $\stackrel{n}{0}$ \\
\hline च் & & $\tilde{0}$ & $\stackrel{m}{o}$ & $\stackrel{t}{0}$ & $\tilde{0}$ & ¿্. & $\tilde{0}$ & $\stackrel{Ð}{0}$ & $\stackrel{v}{0}$ & $\stackrel{n}{0}$ & $\tilde{0}$ & $\tilde{0}$ & $\stackrel{Ð}{0}$ & $\stackrel{\leftrightarrow}{0}$ & $\stackrel{0}{0}$ & $\stackrel{n}{0}$ & ? & $\stackrel{\bullet}{\circ}$ & $\hat{o}$ \\
\hline 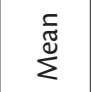 & & $\stackrel{\bullet}{i}$ & $\stackrel{\sim}{N}$ & 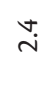 & $\tilde{\sim}$ & $\tilde{n}$ & $\stackrel{0}{i}$ & 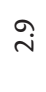 & $\stackrel{\infty}{\sim}$ & $\stackrel{\stackrel{v}{\sim}}{ }$ & 우 & $\bar{i}$ & $\stackrel{\unlhd}{i}$ & $\stackrel{\circ}{m}$ & $\stackrel{n}{n}$ & $\stackrel{\circ}{m}$ & $\stackrel{n}{\sim}$ & $\stackrel{\text { ㄱ. }}{m}$ & $\stackrel{\infty}{\sim}$ \\
\hline 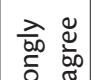 & $\alpha^{\circ}$ & ñ. & $\stackrel{m}{\infty}$ & $\bar{\sim}$ & 으 & $\frac{v}{m}$ & $\lesssim$ & $\stackrel{n}{\sim}$ & $\tilde{N}$ & $\stackrel{n}{\text { กิ }}$ & in & 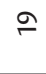 & సี & $\hat{n}$ & $\stackrel{m}{m}$ & $\stackrel{m}{=}$ & $\hat{\check{I}}$ & $a$ & $\stackrel{\hat{\infty}}{\sim}$ \\
\hline$\stackrel{5}{\omega}$ & \# & $\bar{\sigma}$ & in & $\tilde{\sigma}$ & 요 & ন̆ & $\bar{\infty}$ & 이 & r & $\infty$ & $\stackrel{n}{\sim}$ & in & 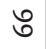 & $\therefore$ & 으 & के & $\stackrel{\infty}{m}$ & $\hat{\imath}$ & 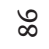 \\
\hline$\underset{\frac{\pi}{20}}{0}$ & $\alpha^{\circ}$ & $\hat{m}$ & $\hat{n}$ & $\hat{\sigma}$ & $\frac{m}{i n}$ & $\stackrel{m}{n}$ & $\hat{ก}$ & ñ. & $\vartheta$ & ث̛ं & ণ & in & $\hat{\stackrel{G}{G}}$ & ๙ิ & $\hat{\text { ¿े }}$ & $\stackrel{m}{\grave{N}}$ & in & $\stackrel{m}{\sim}$ & $\stackrel{m}{i}$ \\
\hline$\stackrel{\mathscr{n}}{0}$ & \# & 음 & 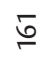 & $\stackrel{g}{\leftarrow}$ & $\stackrel{v}{n}$ & 음 & $\stackrel{\infty}{\sim}$ & $\underline{n}$ & $\underset{\checkmark}{\square}$ & $\underset{\leftarrow}{\mathbb{Z}}$ & $\stackrel{\infty}{\sim}$ & $\widetilde{\sigma}$ & $\stackrel{\infty}{\sim}$ & $\varpi_{\infty}^{\searrow}$ & $\infty$ & オ & $\widehat{\sigma}$ & กี & 드 \\
\hline ì & $\alpha^{\circ}$ & $\hat{\sigma}$ & $\hat{\bar{\nu}}$ & $\stackrel{n}{N}$ & $\approx$ & $\stackrel{m}{m}$ & $\stackrel{\overbrace{}}{\dot{J}}$ & 음 & $\stackrel{2}{-}$ & $\stackrel{m}{r}$ & $\stackrel{m}{r}$ & $\stackrel{m}{r}$ & શ & $\hat{o}$ & $\hat{o}$ & $\stackrel{m}{\sim}$ & nn & 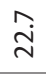 & $\simeq$ \\
\hline 5 & \# & in & ถึ & $\widehat{6}$ & $\stackrel{n}{n}$ & 아 & $\stackrel{v}{\forall}$ & ్․ & in & $\checkmark$ & సี & શิ & $\infty$ & สૂ & $\sim$ & $\stackrel{n}{n}$ & $\because$ & $\infty$ & $\stackrel{m}{m}$ \\
\hline$\stackrel{\Xi}{\varrho}$ & do & $\stackrel{n}{\grave{n}}$ & ֻु & $\hat{\text { in }}$ & $\hat{F}$ & $N$ & $\underset{\text { ị }}{\sigma}$ & $\stackrel{m}{n}$ & $\stackrel{m}{\tilde{N}}$ & $\stackrel{\vartheta}{\dot{v}}$ & $\stackrel{m}{\sim}$ & 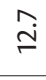 & nn & શ & $\underset{n}{n}$ & $\stackrel{m}{m}$ & $\stackrel{\sim}{\sim}$ & ตे & $\infty$ \\
\hline$<$ & $\#$ & $\infty$ & $\stackrel{\varrho}{2}$ & $\therefore$ & $\tilde{m}$ & 6 & $\approx$ & 아 & ং & $\stackrel{\checkmark}{\checkmark}$ & ) & $\stackrel{\infty}{m}$ & 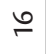 & $\infty$ & $\hat{\sigma}$ & ล & $\stackrel{\infty}{\wedge}$ & $E$ & $\stackrel{\sim}{\sim}$ \\
\hline 츨 & $\alpha^{\circ}$ & 0 & 0 & $\stackrel{m}{\sim}$ & $N$ & 0 & 0 & $\stackrel{m}{m}$ & $\underset{\infty}{m}$ & 0 & $\stackrel{\infty}{\infty}$ & $\stackrel{m}{r}$ & $r$ & $\hat{\sigma}$ & $\stackrel{n}{\sim}$ & $\stackrel{\substack{\infty \\
\infty}}{0}$ & $\tilde{o}$ & $\stackrel{\sim}{\sim}$ & - \\
\hline 离飞 & $\#$ & 0 & 0 & $\checkmark$ & $\bullet$ & 0 & 0 & 음 & $\stackrel{\sim}{\sim}$ & 0 & in & $\checkmark$ & $m$ & 고 & $\stackrel{n}{\forall}$ & $\approx$ & - & $\stackrel{m}{m}$ & $m$ \\
\hline 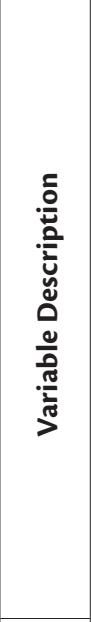 & & 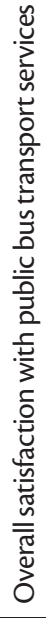 & 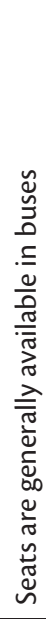 & 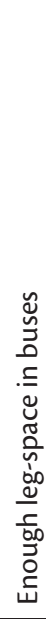 & 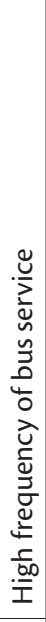 & 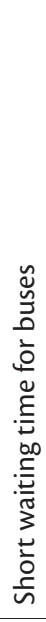 & 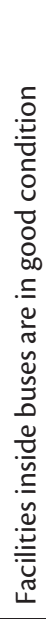 & 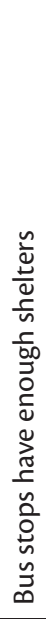 & 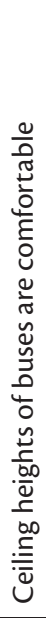 & 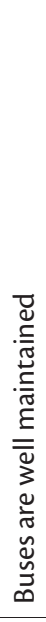 & 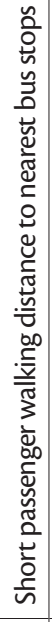 & 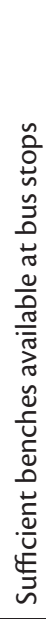 & 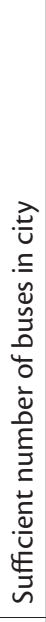 & 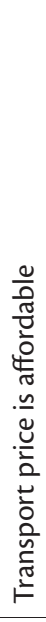 & 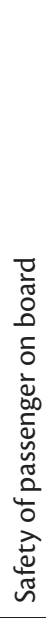 & 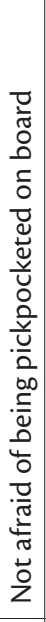 & 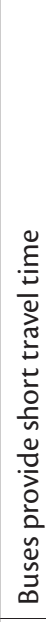 & 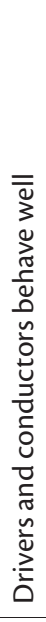 & 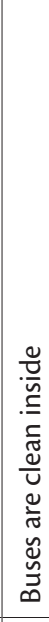 \\
\hline$\frac{\frac{0}{0}}{\frac{\pi}{\frac{\pi}{\pi}}} \frac{0}{\delta}$ & & $\widetilde{0}$ & $\bar{n}$ & $\approx$ & $\tilde{n}$ & w & $\tilde{n}$ & 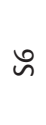 & $n$ & $\stackrel{\infty}{n}$ & ล & 음 & $\bar{n}$ & $\stackrel{\sim}{\sim}$ & $\stackrel{m}{\bar{n}}$ & $\stackrel{v}{\backsim}$ & $\frac{n}{n}$ & $\frac{6}{n}$ & है \\
\hline
\end{tabular}


Only two variables met the expectation of passenger satisfaction of public bus transport services in the city of Abuja. The first, variable S13 (safety of passengers on board), with a mean of 3.5 (mean > 3.0), a standard deviation of 0.6 and a variance of 0.4 , scored 54.3 percent under "agree" and 26.7 percent for "disagree." "Strongly agree" and "strongly disagree" scored 15 percent and 10 percent, respectively; "undecided" scored 0.7 percent. The second variable, S16 (drivers and conductors behave well), also scored a mean of 3.20 (mean > 3.0), a standard deviation of 0.6, and a variance of 0.4. "Agree" scored 39 percent, "undecided" scored 22.7 percent, "strongly agree" scored 12 percent, "disagree" scored 17.3 percent, and "strongly disagree" scored 9 percent. Passengers/respondents were found to be undecided on three variables: S9 (short passenger walking distance to nearest bus stop), with the mean of 3.0 (mean = 3. 0 ), a standard deviation of 0.5 , and a variance of $0.2 ; \mathrm{S} 12$ (transport price is affordable), with a mean of 3.0 (mean $=3.0$ ), a standard deviation of 0.4 , and a variance of 0.2 ; and S14 (personal security on board), with a mean of $3.0($ mean $=3.0)$, a standard deviation 0.3 , and a variance of 0.2 .

The frequency distribution is presented in Figure 3, showing that out of 17 variables analysed, 13 service quality attributes of public bus transport service in the city of Abuja were unsatisfactorily perceived by passengers. Only two variables ( $\mathrm{S} 13$ and S16) met the expectation of the passengers, and passengers were undecided on variables S9 and S14. The conclusion from the analysis is that, generally, passengers of public bus transport are not satisfied with the services provided in Abuja.

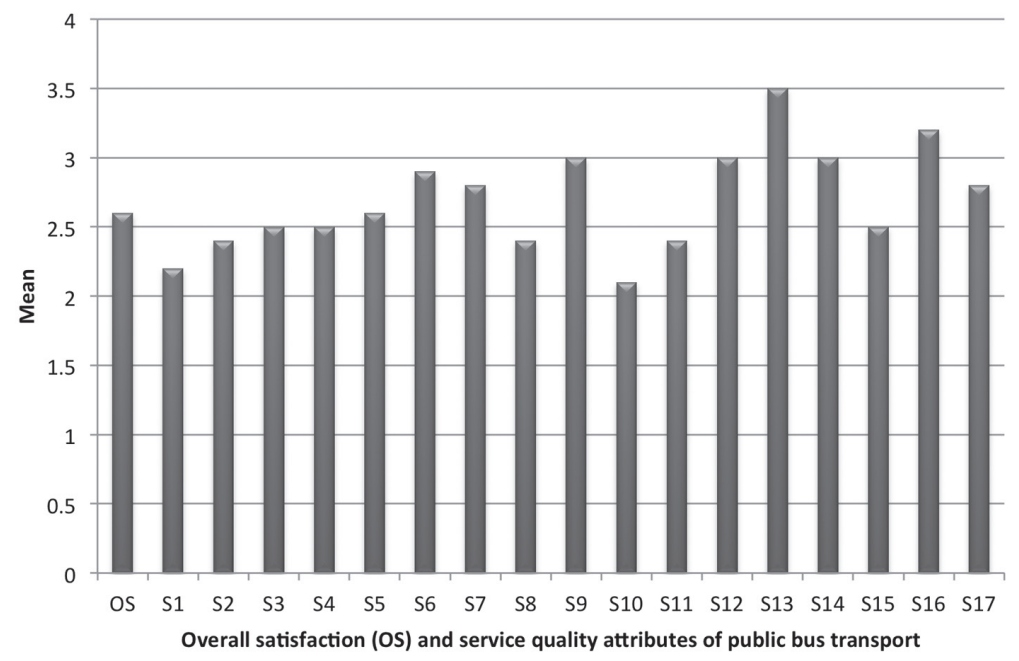

Figure 3. Frequency distribution of overall satisfaction (OS) and service quality attributes 


\section{Principal Component Analysis}

The 17 service quality attributes plus the overall satisfaction were transformed into a matrix of inter-correlation between the variables to know the strength of their correlations. Observation from the correlation matrix (not shown in this paper) shows that there are strong inter-correlations between the variables, which accounted for the existence of many redundancies among some variables. To remove the effect of these strong inter-correlations, as well as include the contributions of the apparently redundant (weakly correlating) variables, PCA was employed to collapse the 17 specific service quality attributes of public bus transport services into a few orthogonal factors that could define broader areas for planning and action by the shareholders in the provision of public bus transport services in the city.

The results of the analysis of the varimax rotated components are presented in Table 4 , which succeeded in reducing the 17 variables to 4 components. The 4 components together explain 83.87 percent of the total explained variance, leaving 16.13 percent unexplained due to other factors not included in this analysis.

Component 1 has an eigenvalue of 4.30 and accounts for 30.47 percent of the total explained variance. The component has high positive loadings on S2 (enough legspace-in buses), S5 (facilities inside buses are in good condition), S7 (ceiling heights of buses are comfortable), S8 (buses are well maintained), and S17 (buses are clean inside). These variables describe conditions in buses that affect passenger satisfaction. Thus, component 1 is identified as "comfort in buses."

Component 2 has high and significant positive loadings for S3 (0.760), S4 (0.813), S9 (0.644), and S15 (0.802). It generally describes service quality attributes affecting passenger satisfaction in getting access to use public bus transport to get to their destinations in the city. Component 2 is then identified as "accessibility to public bus transport services." It has an eigenvalue of 3.38 and accounts for 22.13 percent of the total explained variance.

Component 3 has positive loadings on $\mathbf{S 6}$ (bus stops have enough shelters) and S10 (sufficient benches are at bus stops), with an eigenvalue of 2.72, and it accounts for 16.32 percent of the total explained variance. Component 3 describes the facilities at bus stops in the city. It is, therefore, identified as "bus stop facilities."

Component 4 has an eigenvalue of 2.24 and accounts for 14.95 percent of the explained variance; it has positive loadings on S1 (seats are generally available in buses) and S11 (sufficient number of buses in the city). Component 4 generally 
describes the capacity of public bus transport in Abuja. Component 4 is identified as "adequacy of the capacity of public bus transport services."

\section{Table 4. Result of Varimax Rotated Principal Components Matrix for Service Quality Attributes of Public Bus Transport Services in Abuja}

\begin{tabular}{|c|l|r|r|r|r|}
\hline \multirow{2}{*}{$\begin{array}{c}\text { Variable } \\
\text { Code }\end{array}$} & \multirow{2}{*}{ Variable Description } & \multicolumn{4}{|c|}{ Components } \\
\cline { 3 - 6 } & & 1 & 2 & \multicolumn{1}{c|}{3} & \multicolumn{1}{c|}{4} \\
\hline S1 & Seats are generally available in buses & 0.463 & 0.216 & 0.028 & $0.703^{*}$ \\
\hline S2 & Enough leg-space in buses & $0.812^{*}$ & 0.431 & 0.098 & 0.040 \\
\hline S3 & High frequency of bus services & 0.314 & $0.760^{*}$ & 0.309 & 306 \\
\hline S4 & Short waiting time for buses at bus stops & 0.406 & $0.813^{*}$ & 0.470 & 0.008 \\
\hline S5 & Facilities inside buses are in good condition & $0.842^{*}$ & 0.473 & 0.101 & 0.441 \\
\hline S6 & Bus stops have enough shelters & 0.277 & 0.108 & $0.782^{*}$ & 0.201 \\
\hline S7 & Ceiling heights buses are comfortable & $0.722^{*}$ & 0.213 & 0.240 & 0.111 \\
\hline S8 & Buses are well maintained & $0.874^{*}$ & 0.114 & 0.524 & 0.089 \\
\hline S9 & Short passenger walking distance to bus stops & 0.517 & $0.644^{*}$ & 0.123 & 0.180 \\
\hline S10 & Sufficient benches are available at bus stops & 0.308 & 0.266 & $0.810^{*}$ & 0.283 \\
\hline S11 & Sufficient number of buses in city & 0.215 & 0.541 & 0.117 & $0.646^{*}$ \\
\hline S12 & Transport price is affordable & 0.307 & 0.484 & 0.414 & 0.428 \\
\hline S13 & There is safety of passenger on board & 0.331 & 0.401 & 0.567 & 0.529 \\
\hline S14 & Not afraid of being pickpocketed on board & 0.487 & 0.291 & 0.488 & 0.510 \\
\hline S15 & Buses provide short travel time & 0.520 & $0.704^{*}$ & 0.318 & 0.272 \\
\hline S16 & Drivers and conductors behave well & 0.389 & 0.491 & 0.504 & 0.008 \\
\hline S17 & Buses are clean inside & $0.802^{*}$ & 0.185 & 0.104 & 0.0308 \\
\hline Eigenvalue & & 4.30 & 3.38 & 2.72 & 2.24 \\
\hline$\%$ explained & 30.47 & 22.13 & 16.32 & 14.95 \\
\hline Cumulative \% & 52.60 & 68.92 & 83.87 \\
\hline
\end{tabular}

*Significant loadings are 0.60

$1=$ Comfort in buses

$2=$ Accessibility to public bus transport services

$3=$ Bus stop facilities

4 = Adequacy of capacity

The internal consistency for each of the factors along with the measures of satisfaction were examined using Cronbach's alpha $(\alpha)$. The alphas showed a high reliability (0.80), which exceeded the value of 0.70 recommended by Nunnally (1978). Table 5 depicts the correlation among underlying factors identified. As can be seen 
from Table 5, there is a low correlation between different underlying factors, the highest being 0.383 (between "bus stop facilities" and "adequacy of capacity of public bus transport services"). This means that all the four underlying factors are independent, which indicates that they are measuring unrelated dimensions. The results provide statistical evidence to support the identified underlying dimensions/determinants of passenger satisfaction as comfort in buses, accessibility to public bus transport services, bus stop facilities, and adequacy of the capacity of public bus services.

Table 5. Factor Correlation Matrix

\begin{tabular}{|l|c|c|c|c|}
\hline \multicolumn{1}{|c|}{ Factor } & $\begin{array}{c}\text { Comfort } \\
\text { in Buses }\end{array}$ & $\begin{array}{c}\text { Accessibility } \\
\text { to Public Bus } \\
\text { Transport } \\
\text { Services }\end{array}$ & $\begin{array}{c}\text { Bus Stop } \\
\text { Facilities }\end{array}$ & $\begin{array}{c}\text { Adequacy of } \\
\text { Capacity of Public } \\
\text { Bus Transport } \\
\text { Services }\end{array}$ \\
\hline Comfort in buses & 1.000 & 0.182 & 0.316 & 0.284 \\
\hline $\begin{array}{l}\text { Accessibility to public bus } \\
\text { transport services }\end{array}$ & 0.182 & 1.000 & 0.289 & 0.342 \\
\hline Bus stop facilities & 0.316 & 0.289 & 1.000 & 0.383 \\
\hline $\begin{array}{l}\text { Adequacy of capacity of } \\
\text { public bus transport services }\end{array}$ & 0.284 & 0.342 & 0.383 & 1.000 \\
\hline
\end{tabular}

Extraction method: Principal axis factoring. Rotation method: Oblimin with Kaiser normalization

The overall satisfaction scores were further regressed on the four underlying factors that affect passenger satisfaction in Abuja. This was done to evaluate their effects on the overall satisfaction. The results are presented in Table 6.

Table 6. Regression Model

\begin{tabular}{|c|c|c|c|c|c|}
\hline \multirow[t]{2}{*}{ Independent Variables } & \multicolumn{2}{|c|}{$\begin{array}{l}\text { Unstandardized } \\
\text { Coefficient }\end{array}$} & \multirow{2}{*}{$\begin{array}{c}\text { Standardized } \\
\text { Coefficient }\end{array}$} & \multirow[t]{2}{*}{$\mathbf{T}$} & \multirow{2}{*}{$\begin{array}{l}\text { Sig } \\
(\rho)\end{array}$} \\
\hline & $B$ & Std Error & & & \\
\hline (Constant) & 0.521 & 0.312 & & 1.214 & .067 \\
\hline Comfort in buses & 0.276 & 0.131 & 0.285 & 2.293 & 0.032 \\
\hline $\begin{array}{l}\text { Accessibility to public bus transport } \\
\text { services }\end{array}$ & 0.165 & 0.112 & 0.251 & 2.021 & 0.035 \\
\hline Bus stop facilities & 0.068 & 0.053 & 0.069 & 0.864 & 0.102 \\
\hline $\begin{array}{l}\text { Adequacy of capacity of public bus trans- } \\
\text { port services }\end{array}$ & 0.113 & 0.067 & 0.109 & 0.904 & 0.068 \\
\hline
\end{tabular}

Adjusted $R^{2}=.681, F_{4,52}=52.417, P<001$

Dependent variable: Overall satisfaction 
So, the satisfaction model of public bus transport services is described thus:

$$
\begin{gathered}
\text { Overall satisfaction }=0.52+0.29 \text { (comfort) }+0.25 \text { (accessibility) } \\
+0.07 \text { (bus stop facilities) }+0.11 \text { (adequacy) }
\end{gathered}
$$

The interpretation to the above equation is that the slope of the regression line is significantly greater than zero, indicating that overall satisfaction tends to increase as the four underlying factors increase. The equation also shows that the overall satisfaction of public bus transport services by passengers in Abuja will be 0.52 percent when all 17 service quality attributes are at the zero level. Again, the standardized regression coefficient beta $(\beta)$ values indicate that the underlying factor "comfort" has the greatest impact on passenger overall satisfaction of public bus transport services in Abuja. It is followed by "accessibility" ( $\beta=0.251, \rho=0.035)$, "adequacy" ( $\beta=0.109, \rho=0.068$ ), with "bus stop facilities" having the least impact $(\beta=0.069, \rho=0.102)$. The explanation of the underlying components/factors is presented as follows.

\section{Comfort}

Apparently, the comfort level provided by Abuja city buses is a major element that leaves much to be desired, thereby reducing passenger perceived value and satisfaction with public bus transport services. This finding is in accordance with the findings of Straddling et al. (2007) and Andaleeb et al. (2007) that comfort has the greatest impact on passenger satisfaction. With the exception of some highcapacity buses serving only seven routes (for example, the Abuja First BRT, the green Nationwide Unity buses, and Abuja Urban Mass Transit buses), the operators/owners of other buses do not pay adequate attention to passenger comfort. The basic public bus passenger requirements, such as comfortable seats and open windows for airflow, do not measure up to the standards. A majority of public buses are minibuses, which do not provide adequate legroom or even adequate ceiling heights for standing. Passenger discomfort worsens during rush-hour traffic when many passengers have to travel standing all the way in extremely crowded conditions. The results suggest that if comfort can be increased, rider satisfaction may lead to increased patronage in the use of public bus transport services in the city of Abuja. Comfort is an important consideration for riders of public bus transport and, as such, basic standards for comfort must be established and monitored to ensure that the Abuja bus operators adhere to them. 


\section{Accessibility}

Our model also identified poor accessibility to public bus transport services for a majority of riders in the city. Passengers perceived that bus routes, especially high-capacity bus routes, are not well spread in the city, which, according to riders, has reduced access to most destinations by bus for disadvantaged groups in the Nyanya, Gwagwalada, Karimo, Kuba, and Kuje areas of the city. This requires them to walk relatively long distances before getting to the nearest bus stops to catch a bus. Added to this physical accessibility constraint is the time accessibility constraint, which manifests itself in the long waiting times for buses experienced by many riders due to the low frequency of bus services, mainly caused by vehicle traffic jams. This situation will not encourage people (especially private car owners) to use public bus transport for their daily travels. This is because bus riders do not wish to walk very far to their bus stops, and having arrived at the bus stop, they do not wish to wait for very long (Faulks 1990).

\section{Bus Stop Facilities}

Abuja commuters are not provided with adequate bus stop facilities. Inadequate facilities at bus stops was identified by our model as another source of dissatisfaction of public bus passengers in the city. Very few bus stops (especially those in the city center area) offer appropriate physical structures and facilities for riders. Many bus stops (especially those outside the seven high-capacity bus routes) do not provide protection (shelters) for passengers from sun, rain, dust, pollution, and other basic elements that have significant implications for health and safety. Moreover, passengers have no place to sit for a long wait at bus stops, so there is no alternative but to remain standing. Unless these situations are corrected, expecting private car owners to use public bus transport will not materialize. The effects are that Abuja will continue to clog up, and this situation will be exacerbated in future as the city's population continues to grow. The opportunity costs of the traffic jams are incalculable.

\section{Bus Capacity Adequacy}

Passengers also perceived inadequacy of the capacity of public bus services to serve their needs as a factor that reduced their satisfaction. There is a problem of capacity in public bus transport services in the city of Abuja. The lack of availability of sufficient numbers of buses (especially high-capacity buses) is reflected in the long waiting lines and times, the frantic struggle to board a bus upon its arrival at most stops, and the lack of seating capacity in the buses. If a sufficient number of buses are provided for the Abuja commuters, enabling them to reach their destinations 
comfortably and on time, it will interest more people to use buses for their daily traveling needs.

\section{Conclusions and Recommendations}

This study has shown that passengers are not satisfied with the public bus transport services provided by operators in Abuja. The contribution of this study is the identification of factors that determine passenger satisfaction with the quality of services provided by public bus transport operators in Abuja. The determinants (underlying factors) identified are comfort in buses, accessibility to public bus transport services, bus stop facilities, and adequacy of bus capacity. The study thus provides a direction for public bus transport administration in the city whereby areas for improving services may be identified and passenger satisfaction of public bus transport services may be enhanced.

Based on the findings, we make the following recommendations. Comfort is a huge passenger priority and, as a result, basic standards for bus passenger comfort must be established and monitored by FCT to ensure that the operators abide by them. The six Area Council Governments that make up the FCT should partner with the FCT administration in the provision of buses for intra-city transport services so as to increase bus service frequency and reduce passenger waiting time and walking distance in the area, especially at the peripheries of the city. Like Lagos, "dedicated bus lanes," also known as Bus Rapid Transit (BRT), should be established in Abuja to reduce bus travel time and increase service frequency. This will encourage more people (including private vehicle owners) to use the bus transport system, thereby reducing the number of vehicles on city roads. The government should construct more city link roads, especially in the peripheries of Abuja, and should maintain the existing ones to increase accessibility to encourage bus operators to provide more services to more areas in the city. FCT administration should be faithful to the terms of the public-private partnership agreement it entered into with the private sector in the provision of public bus transport services in the area to enhance private operator operation and serviceability standards required of them to increase passenger satisfaction. Shelters and benches should be provided at bus stops to provide protection from sun and rain for boarding and alighting commuters. 


\section{References}

Aderamo, A. I. 2008. Urbanization and transportation in Nigeria. In Mamman, A. B., C. D. Chup, and S. A. Mashi, eds. Urbanization, Resource Exploitation and Environmental Stability in Nigeria. Joyce Graphics Printers and Publishers, Kaduna.

Aderamo, A. I. 2010. Transport in Nigeria: The case of Kwara State. African Economic and Business Review 8(1). 19-40.

Afolabi, S. 2008. Lagbus. Sunday Sun News, April 5.

Ali, A. N., and P. C. Onokala. 2009. Relative accessibility of the major centres to the intra-urban bus services route network in Enugu City. International Journal of Geography and Regional Planning 1(1): 107-115.

Ali, A. N. 2010. An assessment of the quality of intra-urban bus services in the city of Enugu, Enugu state, Nigeria. Theoretical and Empirical Researches in Urban Management 6(15): 74-91.

Andeleeb, S., S. Haq, H. Mohmadul, and R. I. Ahmed. 2007. Reforming inner-city bus transportation in a developing country: A passenger-driven model. Journal of Public Transportation 10(1): 1-25.

Ashiedu, C. M. 2011. An assessment of bus rapid transit system as a strategy for urban traffic management in Lagos metropolis. Unpublished B.Sc Project, Department of Geography, University of Nigeria, Nsukka.

Asiyanbola, R. A. 2007. Intra-urban transportation, gender and psychological distress in developing countries: Nigeria. Paper presented at PRIPODE Workshop on Urban Population, Development and Environment Dynamics in Developing Countries, June 11-13, Nariobi, Kenya.

Aworemi, J. R., I. A. Abdul-azeez, and O. B. Olaagun. 2009. A study of the performance of public transport company in Niger State, Nigeria. International Journal of Business and Management 4(11): 73-80.

Banjo, G. A. 2008. Integrated mass transit in Nigeria's Cities: Issues, challenge and options. Paper presented at the Lamata National Conference on Public Transportation, Lagos, Ikeja.

Budiono, O. A. 2009. Customer satisfaction in public bus transport: A study of travelers' perceptions in Indonesia. M. Sc Thesis: Service Science Program. Karlstad University. 
Dawan, P. O. 2000. The Geography of Abjua Federal Capital Territory. Famous Asaaly Press, Minna.

Department for Transport. 2003. Understanding customer needs. United Kingdom Department for Transport.

Eboli, L., and G. Mazzulla. 2007. Service quality attributes affecting customer satisfaction for bus transit. Journal of Public Transportation 10(3): 21-34.

Faulks, R. 1990. Bus provision in developing world cities. In Margaret, J.H. (ed.), Developing World of Transport. Grosvenor Press International.

Federal Government of Nigeria. 2010. Draft National Transport Policy.

Friman, M., and T. Garling. 2001. Frequency of negative critical incidents and satisfaction with public transport services. Journal of Retailing and Customer Services 8(2): 105-114.

Friman, M., B. Edvardsson, and T. Garling. 2001. Frequency of negative critical incidents and satisfaction with public transport services. Journal of Retailing and Customer Services 8(2): 95-104.

Gbadamosi, K. T. 2009. A preliminary investigation of the bus rapid transit in Lagos State. Nigerian Geographical Journal 5(2): 70-85.

Gronroos, C. 1984. A service quality model and its marketing implications. European Journal of Marketing 18(4): 36-42.

Ibitoye, A. B., and A. A. Bello. 2012. Effects of congestion on travel time variability along Abuja-Keffi Corridor in Nigeria. Global Journal of Researches in Civil Engineering and Structural Engineering 12(3).

Mishra, R. K., and R. Nandagopal. 1993. State transport undertakings in India: Reforms and privatization strategies. International Journal of Public Sector Management 6(5): 42-55.

National Population Commission (NPC). 2007. Population Census of the Federal Republic of Nigeria. Official Gazette 94(24), Lagos.

Nunnally, J. C. 1978. Psychometric Theory, $2^{\text {nd }}$ ed. New York: McGraw-Hill.

Oiboh, P. 2010. The challenge of public transport in Abuja. Leadership (Abuja), December 22: 4-5. 
Oliver, R. L. 1997. Satisfaction: A Behavioural Perspective on the Consumer. New York: McGraw Hill Companies, Inc.

Oni, S. I. 2002. Metropolization of urban transport development: Example of Lagos, Nigeria. Submitted to Inta 26 Annual Congress, The Hague, Netherlands, June 23-26.

Onokala, P. C. 2001. Urbanization and urban transportation problems in Nigeria. In E. O. Ezeani and N. N. Elekwa (eds.), Issues in Urbanization and Urban Administration in Nigeria. Jamoe Enterprises (Nigeria) Publisher, Enugu.

Straddling, S., M. Carreno, T. Rye, and A. Noble. 2007. Passenger perception and ideal urban bus journey experience. Transport Policy 14: 283-292.

Smerk, G. G. 1974. Urban Mass Transportation, A Dozen Years of Federal Policy. Indiana University Press, Bloomington and London.

Payne, A., and S. Holt. 2001. Diagnosing customer value: Integrating the value process and relationship marketing. British Journal of Management 12: 159-182.

World Bank. 2001. Urban mobility: Profitability and financing of urban public transport microenterprises in Sub-Sharan Africa, an overview of the regional study conducted in Abidjan, Bamako, Harare and Nairobi. SSATP Working Paper No. 54, African Regional World Bank.

\section{About the Author}

Ali Alphonsus NwACHUKWU (alphonsusnwachukwu@yahoo.com) is a Lecturer and Ph.D. student in the Department of Geography, University of Nigeria, Nsukka. His area of specialization is transportation geography. He holds a master's degree in Geography (Transportation Geography) from the University of Nigeria, Nsukka and is currently undertaking research in rural transport patterns and problems. 